未来社会創造事業 探索加速型

「持続可能な社会の実現」領域

年次報告書(探索研究期間)

令和元年度採択研究開発代表者

[研究開発代表者名:木下 政人]

\title{
[京都大学 大学院農学研究科・准教授]
}

[研究開発課題名：ゲノム編集・移植技術による早期養殖魚品種の系統化 ]

実施期間： 令和 2 年 4 月 1 日〜令和 3 年 3 月 31 日 


\section{§1. 研究開発実施体制}

(1)「木下」グループ(京都大学)

(1) 研究開発代表者:木下 政人（京都大学農学研究科、准教授）

(2) 研究項目

・ハックイによる EPA/DHA 合成マダイの作出

•脂質合成代謝関連遺伝子の探索

（メダカを用いた脂質合成遺伝子発現変動の解析）

(2)「家戸」グループ(研究機関名)

(1) 主たる共同研究者:家戸 敬太郎 (近畿大学水産研究所、教授)

(2)研究項目

•脂質合成代謝関連遺伝子の探索

（サクラマスを用いた脂質合成遺伝子発現変動の解析）

•マダイ生殖関連細胞培養法の確立

（親魚生殖巣バイオプシー法の開発）

(3)「酒井」グループ（遺伝学研究所）

(1) 主たる共同研究者:酒井 則良（遺伝学研究所遺伝形質研究系、准教授）

(2)研究項目

•マダイ生殖関連細胞培養法の確立

（生殖細胞培養条件の検討）

\section{§2. 研究開発実施の概要}

EPA、DHA などの高度不飽和脂肪酸(PUFA) は、ヒトや海産魚で重要な栄養素である。多 く海産養殖魚はこの合成酵素を欠くため餌に EPA/DHA を添加する必要があり、餌コストの 上昇と原料魚の乱獲が問題となっている。そこでサステイナブルな養殖を可能にするた め、1） 欠失した酵素を補い EPA/DHA を自家合成できる養殖魚系統の作出、また、2）既 存の遺伝子発現調節による PUFA 蓄積量の増加法の開発を目指した。加えて、系統作出に は数世代の選抜が必要で長期間を必要とするため、3）世代時間を劇的に短縮する移植に よる世代時間の短縮法の開発を目指した。

1） EPA/DHA を自家合成できる養殖魚系統の作出：マダイは EPA/DHA 合成に必要な $\Delta 4-$, $\Delta 5$-不飽和酵素 (fad) 遺伝子を欠く。そこで受精卵へのマイクロインジェクション法を用 いて、マダイの $\Delta 6-\mathrm{fad}$ 遺伝子の下流にメダカ由来の $\Delta 4-, \Delta 5-\mathrm{fad}$ 遺伝子のノックイ 
ンを試みた。その結果、低頻度ではあるが、相同組換えによる正確なノックイン、および 非相同末端修復による挿入が確認された。

2 ）遺伝子発現調節による PUFA 蓄積量の増加法の開発：メダカを用いて、塩分、水温お よび餌（脂質の有無）の 3 条件を変化させ fads 遺伝子群 (fads2a，fads2b，fad2c)の肝臓 での発現量を検討した。その結果、いずれの遺伝子も脱脂餌の投与で発現量が増加した。

3）移植による世代時間の短縮法の開発：まず、マダイ個体からの生殖巣の取り出し方法 を検討した。昨年度に生殖巣からのカテーテル法を試みたが小型魚には適さないことが判 明したため、腹部切開により生殖巣の摘出を試みた。その結果、個体を生かしたまま生殖 巣を摘出する適切な麻酔と切開・縫合方法を決定した。加えて、摘出した生殖巣より生殖 体細胞と生殖原細胞の培養条件の検討を行った。 